UDC $159.9+316.37+316.77$

DOI https://doi.org/10.32405/2413-4139-2020-1(26)-119-126

Bafayev Mukhiddin,

Tashkent, Republic of Uzbekistan

ORCID: https://orcid.org/0000-0002-8501-8458

\title{
SOCIO-PSYCHOLOGICAL DETERMINANTS OF NATIONAL TOLERANCE IN THE CONTEXT OF GLOBALIZATION
}

Summary.

Tolerance is one of the fundamental foundations of achieving social harmony in society. In the developed public consciousness, the tolerance represents quality which is characterized by acceptance by the individual or society of interests, beliefs, beliefs, habits of other people or communities. On the basis of this, it can be argued that the strategy chosen by the State aimed at ensuring peace and stability in Uzbekistan is faithful and far-sighted and is supported by the majority of its citizens.

The theoretical and methodological analysis of the problem under study made it possible to expand the terminology apparatus, formulate a working definition of the concept of "tolerant consciousness", which means - systems of attitudes, value orientations, which creates the prerequisites for establishing interpersonal relations characterized by openness, positive emotional perception of a partner in interaction, the manifestation of empathy in relation to behavioral reactions and values, worldview of other people. By influencing all these factors, it is possible to have a purposeful influence on the formation of tolerant behavior in the youth environment.

The publication presents the relevance of the study of the problem of socio-psychological determinants of the formation of national tolerance in the context of globalization. It is noted that the development of a culture of tolerance and humanism is the most important priority of Uzbekistan's State policy, where respect for the languages, customs and traditions of all nations and nationalities living in its territory is ensured.

Key words: tolerance; national tolerance; internal and external determinants; culture; ethnic identification; cultural and value orientations; interethnic solidarity; ethno psychological features; equality; value.

From world experience, it is known that the stability of a state largely depends on its ability to solve various problems in interethnic relations. In this regard, inter-ethnic harmony becomes a decisive factor for any multinational State.

The Declaration of the Principles of Tolerance [1], adopted at the $28^{\text {th }}$ session of the UNESCO General Conference on 16 November 1995, is an important factor in ensuring peace and harmony among the peoples of the world, equality and cooperation, based on the priority of human rights and freedoms, demonstrates the importance of turning the culture of inter-ethnic harmony and tolerance into universal value.

In recent years, with the generation of cultures around the world, the migration process has become global, with the formation of diasporas with different cultures, life styles and languages in each country, ethnic cultures, ethnic, migration and demographic processes of different nations and peoples, living in its territory, which states that the study of the ethnodynamics of the population is important for the maintenance of peace and stability and is one of the most pressing problems in research in this field [27-31].

Various peoples and ethnic groups have long lived on the territory of Uzbekistan. "Uzbekistan has always been faithful to its traditions in the field of inter-ethnic harmony and religious tolerance and will never deviate from this path. In our country, priority is given to strengthening the atmosphere of mutual respect, friendship and harmony between representatives of different nationalities and religions [2]. Priorities for security, religious tolerance and inter-ethnic harmony in paragraph 5.1. "Strategies 
for action in the five priority areas of development of the Republic of Uzbekistan for 2017-2021", adopted by the President, shows how important it is in society to fulfill such tasks as strengthening civil, interethnic and interreligious peace and harmony; strengthening the independence and sovereignty of the state, strengthening the role of the country as a full-fledged subject of international relations, joining the ranks of developed democracies, creating a zone of security, stability and good-neighbourliness around Uzbekistan [3].

World studies on the formation and improvement of national tolerance have yielded a number of scientific results, including the following: the phenomenon of national tolerance (National University of Singapore); National Advice on pedagogical technology; The components of national tolerance (University of Social Psychology) have been developed; improved mechanisms for national tolerance (University of Trento); methods have been developed to determine the formation of national tolerance (Moscow Institute of Psychology); Improved psychological foundations for the impact of interethnic relations on educational activities (Seoul of National University); revealed the manifestation and influence of social identity in interpersonal relations (University of Social Psychology, Poland).

It is known that tolerance - a personal or social quality, which means recognizing that the world and social environment are multifaceted, and, therefore, views on this world are also different (V. Tishkov). National tolerance - a multifaceted concept that can be considered in psychology from the point of view of personality and his or her relationship, system of values, education and development. It should be noted that the national tolerance - is, on the one hand, the purpose and result of education, along with formation of certain social relations, and on the other hand, the advantage and qualities of the personality which are shown in human behavior and the relations. It should be noted that questions of tolerance, humanity, mutual respect, appreciation, national tolerance Abu Nasr Farabi, Abu Ali ibn Sinna, Abu Raykhan Beruni, Alisher Navoiy, Jaloliddin Davani, Abdurakhmon Jami, Unsurulmaali Keykavus find the reflection in works of encyclopedic scientists of the East, it was also scientifically studied in Amir Timur's heritages, Zakhiriddin Muhammad Babur and others [4-9].

It should also be noted that scientists from far and near abroad G. Andreyeva, A. Asmolov, G. Bardiyer, E. Bogardus, V. Khotines, V. Krisko, T. Mendelberg, J. Mill, J. Locke, G. Olport, J. Olport, V. Petrenko, E. Shlyagina G. Soldatova, G. Stefanenko, P. Stepanov, A. Teschfel, I. Yusupov, A. Walzer, V. Zolotuxina, sed on the studied literature and analytical materials, it can be said that national tolerance - a characteristic feature of multifaceted human relations, a personality trait related to self-esteem, respect for others [13-26].

Questions of national tolerance at the personality are comprehensively analyzed by the Uzbek scientists, including V. Aliyeva, O. Atamirzayeva, M. Hajiyeva, K. Honazarov, P. Kabulov, Z. Kadyrova, R. Murtazayeva, A. Sharipov, S. Shermukhamedov, M. Vakhidova, in scientific research of the Uzbek psychologists by Z. Abidova, B. Botirov, M. Davletshin, E. Gaziyev, A. Jabborov, H. Jabborov, V. Karimova, M. Mamatov, I. Makhmudov, A. Ruziyev, G. Shaumarov, N. Safayev, G. Salomova, F. Tatibayeva, V. Tokareva [4-12]. They considered tolerance in the harmonization of national interests, technology for the formation of tolerant qualities in foster children, tolerant thinking in children in the family, tolerance in the national consciousness, social and moral development of young people through tolerance, ethnic and national identity among primary school students, values in the formation of a national character, ethnic stereotypes in the process of socialization, tolerance in health workers, ethnic and national identity, social perceptions, spiritual education, ethnic values, stereotypes, from the point of view of the spiritual formation of the person in public life.

The article presents research materials on the content, order and application of psychodiagnostic methods aimed at determining the national tolerance of the individual. With the help of these psychodiagnostic methods, an attempt was made to study the relationship between national tolerance and the level of individual cultures, benevolence, indicators of tolerance. Initially, within the framework of our research, we focused on the study of socio-psychological factors that influence the formation of national tolerance at different ages. For this group of adolescents and young adults was carried out "Method for studying ethnic identification" (O. Romanova) and the obtained empirical data (Table 1). 
Indicators of national tolerance at different ages

\begin{tabular}{|c|c|c|}
\hline \multirow{2}{*}{ Age stages } & \multicolumn{2}{|c|}{ Statistical indicators } \\
\cline { 2 - 3 } & Marithm mean & $\mathbf{S}^{2}$ standard deviation \\
\hline Teens first age & 13,61 & 8,25 \\
\hline Adolescence & 16,61 & 11,15 \\
\hline
\end{tabular}

According to the results presented in the table, there is a peculiarity in the manifestation of national tolerance at different ages. In particular, the formation of national tolerance is in adolescence $\mathrm{M}=13,61$ and youthful age $\mathrm{M}=16,61$.

It should be noted that along with human perfection, attitudes towards themselves and other people, peoples and nations are changing. This includes not only understanding the customs, traditions and views of their nation, but also perceiving people of other nationalities as their partners.

As part of our study, an attempt was made to study the relationship between national tolerance and types of tolerance, that is, ethnic tolerance, social tolerance, perfection. Initially, we focused on justifying the relationship of national tolerance with tolerance indices.

Tolerance - tolerance of the way of life, behavior, habits, feelings, opinions, ideas and beliefs of others. Tolerance - a conscious, meaningful and responsible choice of a person, a complex, multifaceted and composite phenomenon that manifests itself through a person's position and actions to establish certain relationships. In this context, in the group of adolescents and young men who participated in the study sought to examine the extent to which tolerance was associated with ethnic social forms and forms of identity in the formation of national tolerance. To this end, they conducted an express survey "Indices of Tolerance" (O. Kravtsova, O. Khukhlaev, G. Soldatova, L. Shaigerova) and "Methodology for studying ethnic identification" (O. Romanova) and received empirical data (Table 2).

According to the table (Table 2), it is established that the high level of national tolerance in the individual is associated with ethnic tolerance to a significant extent $(\mathrm{r}=0,33 ; \mathrm{p} \leq 0,001)$, and a high level of - with social tolerance $(r=0,25 ; \mathrm{p} \leq 0,005)$. The development of national tolerance in the individual leads to an increase in both ethnic and social tolerance. It is also noted that with a moderate formation of national tolerance, there is a significant connection with ethnic tolerance $(r=0,23 ; p \leq 0,05)$ and social tolerance $(\mathrm{r}=0,28 ; \mathrm{p} \leq 0,05)$.

Table 2

Features of the relationship of national tolerance between the types of tolerance in a person

\begin{tabular}{|c|l|c|c|}
\hline $\begin{array}{c}\text { Criteria for national } \\
\text { tolerance }\end{array}$ & \multicolumn{2}{|c|}{ Types of tolerance } & Perfection \\
\cline { 2 - 4 } & $0,33^{*}$ & $0,25^{*}$ & 0,09 \\
\hline high & $0,23^{*}$ & $0,28^{*}$ & 0,16 \\
\hline average & 0,1 & 0,22 & 0,12 \\
\hline below &
\end{tabular}

Note: $* p \leq 0,05, * * p \leq 0,01$

The results show that there is a positive correlation between the types of tolerance in terms of the level of development of national tolerance in a person.

One of the tasks identified in our study is to validate the relationship between types of tolerance (Table 3).

The relationship between the types of tolerance in a person

\begin{tabular}{|c|c|c|c|}
\hline \multirow{2}{*}{ Tolerance indices } & \multicolumn{3}{|c|}{ Tolerance indices } \\
\cline { 2 - 4 } & Ethnic tolerance & Social tolerance & Perfection \\
\hline Ethnic tolerance & one & $0,24 * *$ & $0,19^{* *}$ \\
\hline Social tolerance & $0,24^{* *}$ & one & $0,30^{* *}$ \\
\hline Perfection & $0,19^{* *}$ & $0,30^{* *}$ & one \\
\hline
\end{tabular}

Note: $* p \leq 0,05, * * p \leq 0,01$

According to the results presented in the table, ethnic tolerance in adolescence and adolescence correlates strongly between social tolerance $(\mathrm{r}=0,24 ; \mathrm{p} \leq 0,01)$ and perfection $(\mathrm{r}=0,19 ; \mathrm{p} \leq 0,01)$. 
It is well known that ethnic tolerance - the ability of a person to show tolerance to other ethnic groups, their unfamiliar lifestyle, behavior, national traditions, feelings, relationships, ideas, beliefs, etc.

From this point of view, increasing a person's dignity for his nation, respect for his traditions leads to a positive change in attitude towards other peoples. It should be noted that the positive attitude towards other peoples, the emergence of views, the growing respect for their national traditions, religions and values can be considered as important factors in the formation of their national tolerance.

Culture - the achievement of mankind in social relations in material and spiritual values. Culture is the level of ideological and spiritual development of society, which is determined by its material conditions of life, its life, ideology, education, achievements in science, art and technology. It should be noted that it is most important to study the formation of cultural levels in a person, their influence on national tolerance. In the group of subjects, the methods "Diagnosis of cultural and value orientations" (L. Pochebut) and "Methodology for studying ethnic identification" (O. Romanova) were carried out, important results were obtained (Table 4).

Table 4

Interrelation criterion of national tolerance by types of cultures

\begin{tabular}{|c|c|c|c|}
\hline $\begin{array}{c}\text { Criteria for national tol- } \\
\text { erance }\end{array}$ & \multicolumn{3}{|c|}{ Culture levels } \\
\cline { 2 - 4 } & Traditional culture & Modern culture & $\begin{array}{c}\text { Dynamically developing } \\
\text { culture }\end{array}$ \\
\hline high & $0,44^{* *}$ & $0,25^{*}$ & 0,13 \\
\hline average & $0,35^{*}$ & $0,22 *$ & 0,02 \\
\hline below & $-0,9 *$ & 0,16 & 0,09 \\
\hline
\end{tabular}

Note: $* p \leq 0,05, * * p \leq 0,01$

The results in the table show that a high level of development of national tolerance has a significant correlation with traditional $(r=0,44 ; p \leq 0,01)$ and modern culture $(r=0,25 ; p \leq 0,05)$. Here, traditional culture is characterized by people's orientation towards the past, adherence to traditions, and an interest in history. Consequently, the predominance of past traditions and customs in a person enhances the sense of respect for the values of other peoples. It is also characteristic of modern culture that people are focused on the present, on modern realities. The values of this culture are focused on the development of rights, professions, human abilities, self-renewal and self-government.

The results of the experiments showed that the moderate development of national tolerance is largely associated with traditional $(r=0,35 ; p \leq 0.05)$ and modern culture $(r=0,22 ; p \leq 0.05)$. It should be noted that the low level of development of national tolerance turned out to be a significant contrast with traditional culture $(\mathrm{r}=-0,9 ; \mathrm{p} \leq 0.01)$. It is clear that the low level of national tolerance leads to their rejection of elements of traditional culture.

IP adherence is not found, and the correlation between the national criteria of tolerance and dynamic culture. A dynamically developing culture is characterized by the desire of people to achieve quick results in the future. From this point of view, we see that there is no connection between these two phenomena.

As part of our research, we were able to study the relationship between the levels of personality culture (Table 5).

Table 5

The relationship between cultural and value orientation and types of tolerance in a person

\begin{tabular}{|c|c|c|c|}
\hline \multirow{2}{*}{ Culture levels } & \multicolumn{2}{|c|}{ Types of tolerance } & \multirow{2}{*}{ Perfection } \\
\cline { 2 - 4 } & \multirow{2}{*}{ Ethnic tolerance } & Social tolerance & 0,07 \\
\hline Traditional culture & $0,13^{*}$ & 0,08 & $-0,03$ \\
\hline Modern culture & $-0,06$ & 0,01 & 0,04 \\
\hline Dynamic culture & $-0,006$ & 0,01 & \\
\hline
\end{tabular}

Note: $* p \leq 0.05, * * p \leq 0.01$

According to the data in the table, traditional culture was associated with ethnic tolerance $(\mathrm{r}=0,13 ; \mathrm{p} \leq 0,05)$. It should be noted that traditional culture is a stable non-dynamic culture, which 
is characterized by active development in response to changes in society. Respect for the values of the past, in particular, is due to increased respect for them. Hence, there is a connection between ethnic tolerance and traditional culture.

In addition, we were able to determine the determinants influencing the formation of national tolerance in the context of globalization, based on the diagnostic tests carried out in the course of our study. We divided these determinants on the two and named their external and internal determinants (Table 6).

Socio-psychological determinants national tolerance of the individual

\begin{tabular}{|l|l|}
\hline \multicolumn{1}{|c|}{ External } & \multicolumn{1}{|c|}{ Internal } \\
\hline - the political situation in the country; & - characteristics of the individual (age, gender, temperament); \\
- the socio-historical image of the nation; & - individual personality traits (psychological age, the for- \\
- knowledge of the history and culture of the Motherland & mation of the "Real" and "Ideal" "I"; \\
(in the cognitive sphere); & - self-esteem; \\
- professional orientation of the subject; & - the level of self-activation; \\
- the growth of migration in the country; & - type of behavior in conflict situations; \\
- features of the territory in which the subject lives (diaspo- & - the level of ethnocultural competence; \\
ras living in cities, diasporas living in large cities, megaci- & - psychological readiness for intercultural communication; \\
ties and capitals, living in their homeland (city, district, vil- & - a person's perception of other nationalities; \\
lage) & - experience and skills of intercultural understanding \\
\hline
\end{tabular}

Based on external determinants, we can say that the political situation is also important in the country where the subject lives, the socio-historical image of the nation, as well as whether he lives in a village, district, city, metropolis, capital or in the territory of his homeland.

Studies have shown that people living in urban centers, as well as in the capital, are more tolerant of people than those living in areas and villages. The reason for this is that most other nationalities live in centers, which can be recognized as one of the hallmarks of a multi-ethnic society.

Internal determinants - these are the individual characteristics of the subject, age, gender, temperament, formation of the image of the "real" and "ideal" "self, the type of interpersonal relationships and self-esteem, the level of self-activation, the type of behavior in conflict situations, ethnocultural competence, intercultural psychological readiness for communication, experience and skills of intercultural understanding, the perception of other nationalities by a person also play an important role.

Based on the theoretical literature and the empirical data of our research on the socio-psychological determinants of the formation of national tolerance in the process of globalization, the following conclusions should be drawn.

1. In the works of Eastern scholars, the problem of tolerance is explained in a coherent way by the concepts of generosity, respect for others, kindness emanating from human qualities, hospitality, helping others, care, and so on.

2. While foreign psychologists interpreted the researches on the basis of tolerance, tolerance, mutual aid, support, respect for the dignity of other people, sincerity and ethnic equality in the relations, the Uzbek psychologists interpreted it as spiritual education, spiritual and moral qualities, paid attention in terms of identity, socialization, ethnic stereotypes.

3. Although a person's degree of national tolerance has a positive relationship with such types of tolerance as ethnic tolerance, social tolerance, perfection is embodied as a separate priority factor.

4. The formation of traditional and modern cultures in adolescence and adolescence was based on the fact that they were a mechanism for the development of national tolerance.

Based on the results of the study, the following recommendations were developed.

1. It is necessary to psychologically determine the content of the formation of national tolerance among young people, to develop a system of its psychological forms, methods and means that fully cover the criteria, topics and features of the formation of national tolerance. 
2. Through the formative training of young people, one should teach mutual communication, cooperation, discuss, lead, find solutions to conflicts and respect the culture, values and rights of others.

3. It is necessary to deeply understand that each person is unique, unique reality, and in order not to harm others spiritually and physically, to form a culture of human relations among young people, interpersonal communication skills.

4. To help build relations among members of society in educational and educational institutions on the basis of equality, fraternity, solidarity and interethnic solidarity will give an effective result.

5. It is necessary to teach members of society to treat other cultures, customs, thinking and attitudes as the diversity of the world, to respect their race, nationality, language and religion and to understand the principles of peace as one of the highest human values.

6. It is necessary to teach a person to respect the history, culture, art, language and traditions of his people as an equal and unique feature of world culture, and not to contrast it with other people's values.

\section{References}

1. Deklaraciya principov tolerantnosti YUNESKO [UNESCO Declaration of Tolerance Principles] (2004). Tashkent.

2. Nauchno-populyarnyj spravochnik posvyashchennyj izucheniyu i populyari-zacii Poslaniya Prezidenta Respubliki Uzbekistan SHavkata Mirziyoeva Olij Mazhlisu [opular science reference book dedicated to the study and popularization of the Address of the President of the Republic of Uzbekistan Shavkat Mirziyoyev to the Oliy Majlis] (2019). Tashkent. P. 264-265.

3. Ukaz Prezidenta Respubliki Uzbekistan “O strategii dal'nejshego razvitiya Respubliki Uzbekistan”. PF-4947 № 07.02.2017 [Decree of the President of the Republic of Uzbekistan "On the strategy for the further development of the Republic of Uzbekistan". PF-4947 No. 07.02.2017]. Retrieved from: http://www.lex.uz/docs/3107036.

4. Goziev, E.F., \& Halimov, E.Z. (2006). Komil insonning psihologik tavsifi [Psychological description of the perfect man]. Tashkent. $76 \mathrm{p}$.

5. Goziev, E.F., \& Mamatkulova, R. (2001). Komil insonni tarbiyalash muammolari [Problems of raising a perfect person]. Tashkent. $72 \mathrm{p}$.

6. Mamatov, M.M. (1999). Etnopsihologiya [Ethnopsychology]. Tashkent. 59 p.

7. Safaev, N.S. (2005). Psihologicheskie osobennosti nacional'nogo samosoznaniya studencheskoj molodezhi [Psychological features of the national identity of student youth]. Extended abstract of Doctor's thesis. Tashkent, $38 \mathrm{p}$.

8. Safaev, N.S. (2014). Duhovnost' $i$ nacional'noe samosoznanie lichnosti [Spirituality and national identity of the individual]. Tashkent. $121 \mathrm{p}$.

9. Botirov, B.M. (2011). Y̌zbek millij harakteri shakllanishiga қadriyatlar ta»sirining psihologik hususiyatlari [Psychological features of the influence of values on the formation of the Uzbek national character]. Extended abstract of Doctor's thesis. Tashkent. $22 \mathrm{p}$.

10. Tokareva, V.A. (1989). Psihologiya nravstvennogo razvitiya lichnosti studenta [Psychology of moral development of a student's personality]. Tashkent. P. 44

11. Otamurotov, S. (2008). Globalizaciya i naciya [Globalization and the nation]. Tashkent: Yangi asr avlodi, $201 \mathrm{p}$.

12. Muhamatberdiev, O.B. (1992). Nacional'noe samosoznanie narodov Sr.Azii na sovremennom etape ih razvitiya [National identity of the peoples of Central Asia at the present stage of their development]. Extended abstract of Doctor's thesis. Moscow, $45 \mathrm{p}$.

13. Soldatova, G.U. (1998). Psihologiya mezhetnicheskoj napryazhennosti [Psychology of interethnic tension]. Moscow: Smysl, 252 p.

14. Asmolov, A.G. (2000). Na puti $k$ tolerantnomu soznaniyu [Towards a tolerant consciousness]. Moscow: Smysl, 255 p.

15. Yusupov, I.M. (2008). Tolerantnost'- chto eto takoe? [Tolerance - what is it?]. Kazan'. 128 p.

16. Hotinec, V.Yu. (2000). Etnicheskoe samosoznanie [Ethnic identity]. St. Peterburg, 240 p.

17. Bardier, G.L. (2007). Social'naya psihologiya tolerantnosti [Social psychology of tolerance]. Extended abstract of Doctor's thesis. St. Peterburg. 45 p. 
18. Stefanenko, T.G. (2004). Etnopsihologiya [Ethnopsychology]. Moscow: Aspekt Press, 368 p.

19. Stepanov, P.V. (2006). Vospitanie tolerantnosti u shkol'nikov: teoriya, metodika, diagnostika [Education of tolerance in schoolchildren: theory, methodology, diagnostics]. Moscow. 84 p.

20. Lebedeva, N.M. (2011). Etnicheskaya i kross-kul'turnaya psihologiya [Ethnic and Cross-Cultural Psychology]. Moscow: MAKS Press, P. 61-80.

21. Zolotuhin, V.M. (2001). Tolerantnost' [Tolerance]. Kemerovo. 145 p.

22. Andreeva,G.M.(2010).Social'nayapsihologiya [SocialPsychology].5ed.Moscow:AspektPress,363p.

23. Emory, S. (1933). Bogardus. "A Social Distance Scale" Sociology and Social Research. No. 17. P. 265-271.

24. Social'naya psihologiya [Social Psychology] (2006). 3 ed. Moscow: Omega-L, 352 p.

25. Shlyagina, E.I., \& Enikolopov, S.N. (2011). Issledovanie etnicheskoj tolerantnosti lichnosti.Tolerantnost' $v$ sovremennom mire [Study of the ethnic tolerance of the individual. - Tolerance in the modern world]. Nacional'nyj psihologicheskij zhurnal-National psychological journal. No. 2. P. 80-89.

26. Pochebut, L.G. (2005). Vzaimoponimanie kul’tur. Metodologiya i metody etnicheskoj i krosskul'turnoj psihologii [Mutual understanding of cultures. Methodology and methods of ethnic and cross-cultural psychology]. Psihologiya mezhetnicheskoj tolerantnosti - Psychology of interethnic tolerance. St. Peterburg.

27. Bafaev, M.M., Sanakulova, N.S., \& Boltaev, S.I. Nacional'naya tolerantnost' - osnova mira i stabil'nosti [National tolerance - the basis of peace and stability]. Psihologiya XXI stoletiya - Psychology of the XXI century: materials of the annual Congress (YAroslavl', 27-29 oktyabrya 2017), MAPN.

28. Bafaev, M. (2018). The Factors Influencing Formation of Tolerance Among Young People. "Intellectual Archive". Scientific journal. Vol. 7. No. 3. P. 16-21.

29. Bafaev, M.M. (2015). Nacional'naya tolerantnost' kak faktor razvitiya obshchestva [National tolerance as a factor in the development of society]. Vestnik integrativnoj psihologii-Bulletin of integrative psychology. Vol. 15. P. 126-128.

30. Bafaev, M.M. (2018). Psihologicheskie osnovy tolerantnosti. «Zamonavij psihologiya fanining amalij imkoniyatlari» [Psychological foundations of tolerance. "Zamonaviy psychology fanning amaliy imkoniyatlari”] Mavzusida horizhlik mutahassisliklar ishtirokidagi ilmij-amalij konferenciya materiallariPsychological bases of tolerance. Proceedings of the scientific-practical conference with the participation of foreign experts on "Practical possibilities of modern psychology". Tashkent, P. 128-131.

31. Bafaev, M.M. (2017). Rol' fenomena tolerantnosti v razvitii sovremennogo obshchestva [The role of the phenomenon of tolerance in the development of modern society]. Vestnik NUUz - Bulletin of NUUz. Tashkent, No. 1/3. P. 9-11.

\section{Використані літературні джерела}

1. Декларация принципов толерантности ЮНЕСКО. Ташкент : Адолат, 2004.

2. Научно-популярный справочник, посвященный изучению и популяризации Послания Президента Республики Узбекистан Шавката Мирзиёева Олий Мажлису. - Ташкент : Маънавият, 2019. С. 264-265.

3. Указ Президента Республики Узбекистан «О стратегии дальнейшего развития Республики Узбекистан». ПФ-4947 № 07.02.2017. URL: http://www.lex.uz/docs/ 3107036.

4. Ғозиев Э.Ғ., Халимов Э.З. Комил инсоннинг психологик тавсифи. Тошкент, УзМУ, 2006. 76 б.

5. Ғозиев Э.Ғ., Маматкулова Р. Комил инсонни тарбиялаш муаммолари. Тошкент, ТДТУ, 2001. 72 б.

6. Маматов М.М. Этнопсихология. Тошкент, 1999. 59 б.

7. Сафаев Н.С. Психологические особенности национального самосознания студенческой молодежи: автореф. дис. докт. психол. наук. Ташкент, 2005. 38 с.

8. Сафаев Н.С. Духовность и национальное самосознание личности: монография. Ташкент: Фан, 2014. $121 \mathrm{c}$.

9. Ботиров Б.М. Ўзбек миллий характери шаклланишига қадриятлар таъсирининг психологик хусусиятлари: психол.ф.н. илмий даражасини олиш учун ёзилган диссертация автореферати. Тошкент, 2011. 22 б.

10. Токарева B.A. Психология нравственного развития личности студента: монография. Ташкент : Фан, 1989. С. 44. 
11. Отамуротов С. Глобализация и нация. Тошкент : Янги аср авлоди, 2008. 2016.

12. Мухаматбердиев О.Б. Национальное самосознание народов Ср.Азии на современном этапе их развития: автореф. докт. социол. наук. М., 1992. 45 с.

13. Солдатова Г.У. Психология межэтнической напряженности. М. : Смысл, 1998. - 252 с.

14. Асмолов А.Г. На пути к толерантному сознанию. М. : Смысл, 2000. 255 с.

15. Юсупов И.М. Толерантность - что это такое? Казань, 2008. 128 с.

16. Хотинеи В.Ю. Этническое самосознание. СПб. : Алетейя, 2000. 240 с.

17. Бардиер Г.Л. Социальная психология толерантности: автореф. дис. ... д. психол. н. СПб. : 2007., 45 c.

18. Стефаненко Т.Г. Этнопсихология: учебник для вузов. 3-е изд., испр. и доп. М. : Аспект Пресс, 2004. $368 \mathrm{c}$.

19. Степанов П.В. Воспитание толерантности у школьников: теория, методика, диагностика. М.: АПКиППРО, 2006. $84 \mathrm{c.}$

20. Лебедева Н.М. Этническая и кросс-культурная психология: учеб. для высших учебных заведений. М. : МАКС Пресс, 2011. С. 61-80.

21. Золотухин B.M. Толерантность. Кемерово, 2001. 145 с.

22. Андреева Г.М. Социальная психология. 5-е изд. М. : Аспект Пресс, 2010. 363 с.

23. Emory S. Bogardus. "A Social Distance Scale." Sociology and Social Research 1933. No. 17. P. 265-271.

24. Социальная психология. 3-е изд. М. : Омега-Л., 2006. 352 с.

25. Шлягина Е.И., Ениколопов С.Н. Исследование этнической толерантности личности. Толерантность в современном мире. Национальный психологический журнал. 2011. № 2. С. 80-89.

26. Почебут Л.Г. Взаимопонимание культур. Методология и методы этнической и кросскультурной психологии. Психология межэтнической толерантности. СПб., 2005.

27. Бафаев М.М., Санакулова Н.С., Болтаев С.И. Национальная толерантность - основа мира и стабильности. Психология XXI столетия: материалы ежегодного Конгресса (Ярославль, 27-29 окт. 2017), МАПН.

28. Bafaev M. The Factors Influencing Formation of Tolerance Among Young People. "Intellectual Archive". Scientific journal. 2018. Vol. 7. No. 3. P. 16-21.

29. Бафаев М.M. Национальная толерантность как фактор развития общества. Вестник интегративной психологии. 2015. Вып. 15. С. 126-128.

30. Бафаев М.М. Психологические основы толерантности. «Замонавий психология фанининг амалий имкониятлари» мавзусида хорижлик мутахассисликлар иштирокидаги илмий-амалий конференция материаллари. Тошкент, 2018. Б. 128-131.

31. Бафаев М.М. Роль феномена толерантности в развитии современного общества. Вестник НУУз. Ташкент, 2017. № 1/3. Б. 9-11.

Бафаєв М.М. Соціально-психологічні детермінанти формування національної толерантності в умовах глобалізації.

Анотація.

У публікаиії представлені актуальність, термінологічний апарат, результати дослідження проблеми «Соціально-психологічні детермінанти формування національної толерантності в умовах глобалізації». Відзначається, щцо розвиток культури толерантності - ие найважливіший пріоритет державної політики Узбекистану, де забезпечується шанобливе ставлення до мов, звичаїв і традииій усіх націй і народностей, щзо проживають на ї̈ території.

Ключові слова: толерантність; національна толерантність; внутрішні та зовнішні детермінанти; культура; етнічна ідентифікація; культурно-ціннісні орієнтації; міжнаціональна солідарність; етнопсихологічні особливості; рівність; ијінність. 